\title{
The Genetic Constitution of Certain Penicillinase Micro- mutants in Staphylococcus aureus
}

\author{
By M. H. RICHMOND \\ Department of Molecular Biology, University of Edinburgh, \\ West Mains Road, Edinburgh 9
}

(Received 13 January 1966)

\begin{abstract}
SUMMARY
Treatment of the naturally occurring magno-inducible Staphylococcus aureus strain 8325-18 with ethyl methane sulphonate allows the isolation of mutants which synthesize much less penicillinase than the parent. Both inducible and constitutive mutants can be isolated and their activities range from $0 \cdot 1$ to $50 \%$ of the basal activity of the wild type. All the mutants examined here synthesize a penicillinase indistinguishable from the wild type in terms of substrate profile and reaction with specific anti-exo-penicillinase serum. Examination of the genetic make-up of the mutants shows that they all possess an intact inducibility $\left(i^{+}\right)$gene. It is theoretically possible that the lesion in the micro-inducible strains could lie in the penicillinase structural gene, but such a location is extremely unlikely for the microconstitutives. The most likely location for these mutants is a region analogous to the operator of the lactose segment of Escherichia coli; however, their properties are incompatible with the recent suggestion that the operator region should be divided into two distinct parts.
\end{abstract}

\section{INTRODUCTION}

Novick (1963) has shown that penicillinase micro-mutants may be obtained from cultures of Staphylococcus aureus after treatment with mutagens. Two classes were observed: micro-inducible strains, in which the uninduced enzyme level was less than that found in the wild type but in which the induction ratio was normal ( 40-fold); and micro-constitutive strains, in which the uninduced level was less than the wild type but in which the induction ratio was approximately $1 \cdot 0$. Within this classification, strains have been isolated with basal penicillinase activities ranging from about $0 \cdot 1$ to $50 \%$ of normal. Some micro-inducible strains synthesize normal amounts of penicillinase protein with low specific enzyme activity, but all the micro-strains examined here synthesize penicillinase indistinguishable from the wild type.

Penicillinase micro-mutants have also been obtained from wild-type Bacillus licheniformis by treatment with ethyl methane sulphonate or nitroso-guanidine (Dubnau \& Pollock, 1965). In these mutants the enzyme level varied from 0.25 to $5 \%$ of normal and some of these appear to make a 'mutein'-or mutant protein (Collins et al. 1965).

The genes responsible for penicillinase synthesis are normally carried on an extrachromosomal particle-or plasmid (Novick, 1963; Richmond, 1965a). So far a number of different types of plasmid have been identified on the basis of the genetic markers accompanying the penicillinase genes on the plasmid and the immunological properties of the penicillinase molecule itself (Novick \& Richmond, 1965; 
Richmond, 1965a). Of the ten different plasmid types that can be distinguished on these grounds, only three $(\alpha, \beta$ and $\gamma)$ are involved in the work described here. All the micro-mutants which are studied in this account are carried on the $\alpha$-plasmid since they are obtained by treatment of strain $\left(\alpha . i^{+} p^{+}\right)$with mutagens. The only difference between the $\alpha$ - and $\gamma$-plasmids is that the latter carries genes responsible for erythromycin resistance $\left(\mathrm{em}^{\mathrm{B}}\right)$. Transduction of the $\gamma$-plasmid to cells already containing $\alpha$ leads to recombination between $\alpha$ and $\gamma$ and such recombined plasmids $(\alpha \ldots \gamma)$ have been used in certain experiments described below which require selection of transductants with erythromycin.

The $\beta$-plasmid differs from $\gamma$ in that recombination with $\alpha$ after transduction is rare: instead plasmid diploids are established (Richmond, 1965b). Such diploids have been used in these experiments to test some of the control properties of micromutants in much the same way that Jacob \& Monod (1961) have used merodiploids of the lactose system in Escherichia coli to investigate the control properties of the lac genes.

So far two plasmid-borne genetic regions determining penicillinase synthesis have been identified in Staphylococcus aureus. One $\left(i^{+}\right)$confers inducible properties on enzyme synthesis, and the other $(p)$ is the structural gene for the penicillinase molecule itself (Novick, 1963; Richmond, 1965a). Since all the mutants examined here seem to synthesize wild-type penicillinase, one question to be answered is whether their micro-properties are caused by a mutation in the $i$-gene, or elsewhere. The genetic experiments reported later suggest that both micro-inducible and microconstitutive mutants carry an intact $i^{+}$gene and it is necessary, therefore, to invoke the presence of a second control region in the penicillinase system to explain the behaviour of these micro-mutants. Mapping experiments show that in the case of strains $\mu 1, \mu 15, \mu 56$ and $\mu 88$ at least, this region probably lies between the $i_{1}-$ and $p_{2}{ }^{-}$loci, and this location suggests-by analogy with mutants in the $\beta$-galactosidase system of Escherichia coli (Jacob \& Monod, 1961)—the presence of a genetic region of the 'operator' type. In the latest version of the 'operator-hypothesis' for the control of enzyme synthesis, Jacob \& Monod (1965) suggest that the operator as originally envisaged must be divided into two parts, one responsible for the recognition of the $i$-gene product (still called the operator) and the other controlling the rate of expression of the operon (the promoter). The properties of the penicillinase micro-inducible mutants could be caused by a mutation in a promoter, but the micro-constitutives cannot readily be interpreted on the basis of a divided operator/ promoter since a single mutational change in these strains affects both the recognition of the $i$-gene product and the rate of expression of the structural gene. It appears therefore, that an operator region may be involved in the penicillinase system of $S$. aureus, but its subdivision into two parts, as in the $\beta$-galactosidase system, does not need to be postulated, A preliminary account of some of this work has appeared previously (Richmond, 1965a, 1966).

\section{METHODS}

Organisms. All the micro-mutants examined in this paper (see Table 1) were obtained from strain $8325\left(\alpha \cdot i^{+} p^{+} . H^{\mathrm{R}} . e m^{\mathrm{s}}\right)$ (Novick \& Richmond, 1965) by treatment with ethylmethane sulphonate (Novick, 1963). They were subcultured 
routinely on blood agar and the presence of the $\alpha$-plasmid checked at each subculture by showing the presence of the $\boldsymbol{H g}^{\mathrm{R}}$ marker with a mercuric chloride disc (Green, 1962). Other stock strains, e.g. 8325 $\left(\alpha \cdot i^{+} p^{+} . \mathrm{Hg}^{\mathrm{R}} \cdot \mathrm{em}^{\mathrm{s}}\right), 8325(\mathrm{~N}), 147$ $\left(\beta . i^{-}{ }_{223} p^{+} . H g^{\mathrm{R}} \cdot e m^{\mathrm{s}}\right)$, and $147\left(\beta . i^{+} p^{+} \cdot H g^{\mathrm{R}} \cdot e m^{\mathrm{s}}\right)$ have already been described (Novick \& Richmond, 1965). The recombinant strain $8325\left(\alpha \cdot i^{-}{ }_{1} p^{+} . \mathrm{Hg}^{\mathrm{R}} \ldots \gamma \cdot \mathrm{em}^{\mathrm{R}}\right)$ was obtained by transducing strain $8325\left(\alpha . i^{-}{ }_{1} p^{+} \cdot \mathrm{Hg}^{\mathrm{R}} \cdot \mathrm{em}^{\mathrm{s}}\right)$ with phage $80 \alpha$ (Novick, 1963) propagated on strain $258\left(\gamma \cdot i^{+} p^{+} . \mathrm{Hg}^{\mathrm{R}} . \mathrm{em}^{\mathrm{R}}\right.$ ) (Hashimoto, Kono \& Mitsuhashi, 1964; Richmond, 1965a) and selecting on erythromycin agar. All the micro-strains were then converted to the erythromycin-resistant state $\left(\mathrm{em}^{\mathrm{B}}\right)$ by transduction with phage obtained by irradiating the constitutive strain $8325\left(\alpha . i^{-}\right.$ $\left.p^{+} . H g^{\mathrm{R}} \ldots \gamma \cdot e m^{\mathrm{R}}\right)$. The transductants were selected on medium containing $10 \mu \mathrm{g}$. erythromycin $/ \mathrm{ml}$. and the micro-strains picked after staining the colonies to show the low amount of penicillinase synthesised.

Media and conditions for induction of penicillinase. The organisms were grown routinely in CY medium (Novick \& Richmond, 1965) and induced by addition of $0.5 \mu \mathrm{g}$. methicillin/ml. The specific enzyme activity (enzyme units/mg. dry wt. bacteria) was measured $3.75 \mathrm{hr}$ after induction (Richmond et al. 1964). The amount of penicillinase synthesized by strains was determined by staining colonies growing on CY medium agar containing $0.2 \%(\mathrm{w} / \mathrm{v})$ starch with penicillin + iodine solution as described by Novick \& Richmond (1965).

Transduction and selection of transductants. The phages used for transduction were carried as prophage by lysogenic donor strains. Exponentially growing cultures of the donor strains were centrifuged and the bacteria resuspended to a density of $5 \times 10^{8}$ organisms $/ \mathrm{ml}$. in physiological saline. The suspension of organisms $(2 \mathrm{ml}$. $)$ was irradiated in a Petri dish (Hanovia lamp), and $1.5 \mathrm{ml}$. immediately transferred to $1.5 \mathrm{ml}$. pre-warmed CY medium containing $0.3 \%(\mathrm{w} / \mathrm{v})$ glucose. The culture was incubated at $35^{\circ}$ for $1 \mathrm{hr}$, then centrifuged, and the phage freed from bacteria by membrane filtration. This method of preparation usually gave phage titres of about $10^{9}$ p.f.u./ml. for both strains 8325 and 147 .

Transduction experiments were carried out as described by Novick (1963; Novick \& Richmond, 1965). The transductants were usually selected with penicillin as described by Richmond (1965b). Where selection of the $H g$ marker was required, the transductants were plated at a density of $5 \times 10^{7}$ recipient organisms/plate on mercuric chloride agar of the following composition: 'Oxoid' peptone, $2 \%(\mathrm{w} / \mathrm{v})$; $\mathrm{NaCl}, 0.5 \%(\mathrm{w} / \mathrm{v})$; Davis agar, $1 \%(\mathrm{w} / \mathrm{v})$; adjusted to $\mathrm{pH} \mathbf{7 \cdot 4}$ (Moore, 1960) Mercuric chloride was added to the molten agar to a final concentration of $65 \mu \mathrm{g} . /$ $\mathrm{ml}$. immediately before pouring. The plates were used within $\mathbf{2 4} \mathrm{hr}$ of mixing the peptone and the $\mathrm{HgCl}_{2}$ solution. Selection with erythomycin was carried out as described above.

Immunological titration of $A$ - and $C$-type penicillinase. The presence of A- or C-type penicillinase was detected with specific anti-exo-penicillinase serum as described by Richmond $(1965 b, c)$.

\section{RESULTS}

Characteristics of mutants

Table 1 shows the specific activity of exponentially growing cultures of the micromutants considered below. Among the micro-inducible strains, the uninduced 
enzyme level varied from $0 \cdot 1$ to $10 \%$ of normal, whereas among the micro-constitutives the variation is from $2-10 \%$. The induction ratio is close to normal (40-fold) in all the micro-inducible strains except one (strain $\mu$ 89), where the ratio is about 15.

All the mutants were examined to see whether there is any evidence for their being double mutants or deletions. Ultraviolet light-induced revertants have been obtained from the micro-inducible strains $\mu 1, \mu 15$ and $\mu 33$ and from the microconstitutive strain $\mu$ 56. In all cases the revertants were indistinguishable from the wild-type strain $8325\left(\alpha \cdot i^{+} p^{+}\right)$. These observations suggest that each of these mutants carry point mutations.

Table 1. Specific enzyme activity of micro-mutants

\begin{tabular}{|c|c|c|c|c|}
\hline \multirow[b]{2}{*}{$\begin{array}{c}\text { Strain No. } \\
\mathbf{8 3 2 5}\left(\alpha . i^{+} p^{+}\right)\end{array}$} & \multirow[b]{2}{*}{$\begin{array}{c}\text { Phenotype } \\
\text { Magno-inducible }\end{array}$} & \multicolumn{2}{|c|}{ Specific enzyme activity } & \multirow{2}{*}{$\begin{array}{c}\text { Induction } \\
\text { ratio } \\
\mathbf{3 0}\end{array}$} \\
\hline & & $\begin{array}{l}\text { Uninduced } \\
10\end{array}$ & $\begin{array}{l}\text { Induced } \\
\mathbf{3 0 0}\end{array}$ & \\
\hline$\mu 1$ & & 0.002 & 0.08 & 36 \\
\hline$\mu 15$ & & 0.006 & 0.02 & 33 \\
\hline$\mu \mathbf{3 3}$ & Micro-inducible & 0.02 & 0.6 & 30 \\
\hline$\mu 88$ & & $0 \cdot 13$ & 5 & 38 \\
\hline$\mu 89$ & & 0.02 & $0 \cdot 3$ & 15 \\
\hline$\mu \mathbf{5 5}$ & & 0.03 & 0.035 & $1 \cdot 2$ \\
\hline$\mu 56$ & Micro-constitutive & $1 \cdot 1$ & $1 \cdot 6$ & $\mathbf{1 \cdot 2}$ \\
\hline$\mu 102$ & & 0.27 & $0 \cdot 3$ & $1 \cdot 0$ \\
\hline
\end{tabular}

Specific enzyme activity = enzyme units/mg. dry wt. bacteria.

Induction ratio $=\frac{\text { Specific enzyme activity of induced culture }}{\text { Specific enzyme activity of uninduced culture }}$

Crude preparations of the enzyme synthesized by each mutant strain were indistinguishable from normal in their reaction with specific anti-exo-penicillinase serum (Richmond, 1963, 1965 c). Examination of the relative rates of hydrolysis of benzyl penicillin, phenoxymethyl penicillin, ampicillin, 6-amino penicillanic acid and quinacillin by the enzymes synthesized by the mutant strains showed no significant difference in behaviour from the wild-type enzyme. The extracellular enzymes synthesized by fully induced cultures of strain $\mu 33$ (micro-inducible) and $\mu 56$ (micro-constitutive) were purified. The specific enzyme activity of both preparations was close to that of the purified wild-type enzyme (Richmond, 1963) and there was no difference in immunological behaviour between the mutant and the wild type. This is, therefore, prima facie evidence that micro-strains are not caused by mutations in the penicillinase structural gene. However, a mutation in a structural gene can theoretically lead to a mutant protein which is indistinguishable from the wild type in substrate profile and reaction with specific antiserum, and the possibility of this being the case here is discussed later.

\section{Genetic constitution of the micro-mutants}

One type of mutation that could give rise to micro-strains is one in the controlling $\left(i^{+}\right)$-gene. In the case of the micro-inducible strains, the mutation would have to alter the properties of the $i$-gene so that its product became an exceptionally effective repressor of the structural gene, yet retained its ability to recognize the inducer. To give a micro-constitutive phenotype, the mutant would have to modify the 
$i$-gene product so that recognition of the inducer was lost in addition to its increased effectiveness as a repressor.

In practice, any alteration in the properties of the $i$-gene should be detected by examining the effect of the micro-mutation carried on one penicillinase plasmid on a known constitutive $\left(i^{-}\right)$genotype carried on a second plasmid in the same cell (Richmond, 1965b; Novick \& Richmond, 1965). If the micro-mutation is in the $i$-gene, it should express its effect when 'trans' to the $\left(i^{-}\right)$constitutive gene; that is, a plasmid bearing a micro-mutation in the $i$-gene should repress the uninduced level of penicillinase formation by a constitutive plasmid to the micro-level.

Table 2. Physiological characteristics of parent strains, diploids and segregants in an experiment in which phage from strain $147\left(\beta . i^{-}{ }_{223} p^{+}\right)$was used to construct a diploid with the micro-inducible strain, $\mu 33$.

\begin{tabular}{|c|c|c|c|}
\hline & \multicolumn{2}{|c|}{ Specific enzyme activity } & \multirow[b]{2}{*}{$\begin{array}{l}\text { Induction } \\
\text { ratio }\end{array}$} \\
\hline & Uninduced & Induced & \\
\hline \multicolumn{4}{|l|}{ Parent strain } \\
\hline $147\left(\beta . i^{-}{ }_{223} p^{+}\right)$ & 158 & 317 & 2 \\
\hline Micro-inducible strain, $\mu \mathbf{3 3}$ & 0.02 & 0.65 & 32 \\
\hline Diploid* & $5 \cdot 8$ & 296 & 51 \\
\hline \multicolumn{4}{|l|}{ Segregants } \\
\hline $\operatorname{S325}\left(\beta . i^{-}{ }_{223} p^{+}\right)$ & 161 & 288 & $1 \cdot 8$ \\
\hline Micro-strain $(\mu$ 33?) & 0.017 & $0 \cdot 8$ & 46 \\
\hline \multicolumn{4}{|l|}{ Stock strains } \\
\hline $147\left(\beta . i^{+} p^{+}\right)$ & $5 \cdot 2$ & 271 & 52 \\
\hline $8325\left(\beta . i^{-}{ }_{223} p^{+}\right)$ & 150 & 274 & $1 \cdot 8$ \\
\hline
\end{tabular}

\footnotetext{
* The activities quoted for the diploid cultures are the average of measurements on six diploid clones.

Specific enzyme activity = enzyme units/mg. dry wt. bacteria.

Induction ratio $=\frac{\text { Specific enzyme activity of induced culture }}{\text { Specific enzyme activity of uninduced culture. }}$
}

Appropriate diploid cultures were constructed by using the micro-strains as recipients in a transduction experiment in which the transducing phage was obtained by irradiating the magno-constitutive strain $147\left(\beta . i^{-}{ }_{223} p^{+}\right)$. The recipient cultures were infected at a multiplicity of $1 \cdot 1$ p.f.u./recipient organism, and the transductants selected on agar containing penicillin (see Methods). Since recombination between components of an $\alpha / \beta$ plasmid diploid are uncommon (Richmond, 1965b), only two types of segregant are expected from this type of diploid. One of them (carrying the $\beta . i^{-}{ }_{223} p^{+}$genome) is constitutive (see Table 2 for enzyme levels) whereas the other (carrying the $\alpha$.micro. $p^{+}$genome) has the phenotype characteristic of the particular micro-strain involved (Table 1). These two segregants may readily be distinguished from the diploid (see Table 2 for typical enyzme levels), and from one another, by comparing the relative size of the penicillinase haloes produced by uninduced colonies growing on starch/CY agar after staining with penicillin +iodine (Novick \& Richmond, 1965). Table 2 gives the physiological characteristics of the parent, diploid and segregant strains obtained when the recipient was the micro-inducible strain $\mu 33$. The presence of the $\mu 33$ genome in the uninduced diploid did not lower the specific activity (enzyme units/mg. dry wt. 
bacteria) to the micro-level but only to the values characteristic of the wild-type parent. These results, therefore, suggest that the mutation in the micro-inducible strain $\mu 33$ does not lie in the $i$-gene, and comparable results have been obtained with all the other micro-inducible strains tested $(\mu 1, \mu 15, \mu 88$ and $\mu 89)$. Similarly, when the micro-constitutive strains were used as recipients (e.g. $\mu 55, \mu 56$ and $\mu 102$, Table 3), the diploid containing both the micro- and the magno-constitutive genomes was fully inducible with a normal basal level, so the micro-constitutive strains also behave as though they have a normal $i$-gene $\left(i^{+}\right)$.

Table 3. Physiological characters of parent strains, diploids and segregants in an experiment in which phage from strain $147\left(\beta . i^{-}{ }_{223} p^{+}\right)$was used to construct a diploid with the micro-constitutive strains $\mu 55, \mu 56$ and $\mu 102$.

\begin{tabular}{|c|c|c|c|}
\hline & \multicolumn{2}{|c|}{ Specific enzyme activity } & \multirow{3}{*}{$\begin{array}{l}\text { Induction } \\
\text { ratio }\end{array}$} \\
\hline & Uninduced & Induced & \\
\hline \multicolumn{3}{|l|}{ Parent strains } & \\
\hline $147\left(\beta . i^{-}{ }_{223} p^{+}\right)$ & 161 & 298 & $1 \cdot 8$ \\
\hline$\mu \mathbf{5 5}$ & 0.02 & $0 \cdot 035$ & $1 \cdot 7$ \\
\hline$\mu 102$ & $\mathbf{0} \cdot \mathbf{3 2}$ & $\mathbf{0} \cdot \mathbf{3 0}$ & $1 \cdot 0$ \\
\hline$\mu 56$ & $1 \cdot 3$ & $\mathbf{2 \cdot 0}$ & $1 \cdot 5$ \\
\hline \multicolumn{4}{|l|}{ Diploid } \\
\hline In $\mu \mathbf{5 5}^{*}$ & 4.2 & 281 & 69 \\
\hline In $\mu 102^{*}$ & $6 \cdot 1$ & 268 & 44 \\
\hline In $\mu 5^{*}$ & $8 \cdot 3$ & 249 & 31 \\
\hline \multicolumn{4}{|l|}{ Segregants } \\
\hline $8325\left(\beta . i^{-}{ }_{223} p^{+}\right)$from diploid in $\mu 55$ & 142 & 307 & $2 \cdot 1$ \\
\hline $8325\left(\beta . i^{-}{ }_{223} p^{+}\right)$from diploid in $\mu 102$ & 168 & 301 & $\mathbf{1 \cdot 9}$ \\
\hline $8325\left(\beta . i^{-}{ }_{223} p^{+}\right)$from diploid in $\mu 56$ & 171 & 308 & $\mathbf{1} \cdot \mathbf{8}$ \\
\hline Micro-strain $(\mu 55 ?)$ & 0.02 & 0.035 & $\mathbf{1} \cdot \mathbf{7}$ \\
\hline$(\mu 102 ?)$ & $0 \cdot 32$ & $0 \cdot 21$ & $0 \cdot 7$ \\
\hline$(\mu 56 ?)$ & $1 \cdot 8$ & $\mathbf{3 \cdot 0}$ & $1 \cdot 7$ \\
\hline \multicolumn{4}{|l|}{ Stock strains } \\
\hline $147\left(\beta . i^{+} p^{+}\right)$ & $4 \cdot 6$ & 238 & 51 \\
\hline $8325\left(\beta . i^{-}{ }_{223} p^{+}\right)$ & 171 & $\mathbf{3 1 7}$ & $\mathbf{1} \cdot \mathbf{8}$ \\
\hline
\end{tabular}

* The activities quoted for the diploid cultures are the average values obtained with six diploid clones of each strain.

Specific enzyme activity = enzyme units/mg. dry wt. bacteria.

Induction ratio $=\frac{\text { Specific enzyme activity of induced culture }}{\text { Specific enzyme activity of uninduced culture }}$

Examination of the diploid comprising the $\left(\beta . i^{-}{ }_{223} p^{+}\right.$. magno-constitutive $)$and $\left(\alpha . i^{+} p^{+}\right.$.micro-constitutive) plasmids can also show whether the micro-mutation on the $\alpha$-plasmid can be counteracted by a product of the $\beta$-plasmid acting 'trans' in the diploid. If the wild type can correct a micro-mutation in the penicillinase system, then the diploid between the $\left(\beta \cdot i^{-}{ }_{223} p^{+}\right)$and $\left(\alpha \cdot i^{+} p^{+}{ }_{\mathrm{A}}\right.$.micro-constitutive) plasmids should synthesize both $A$ - and C-type penicillinase (characteristic of the $\alpha$ - and $\beta$-plasmids respectively-Richmond, 1965 a) to the full wild-type level in the presence of inducer. However, if the micro-mutation cannot be corrected by the wildtype plasmid acting 'trans', then the diploid should form C-type enzyme at the full induced rate (i.e. about 300 units/mg. dry wt. bacteria), whereas the A-type enzyme should only be present at the level found in the micro-state (e.g. 1.6 units/ 
mg. dry weight bacteria in the case of the $\mu 56$; see Table 1 ). Measurement of the amount of A- and C-type enzyme synthesized by the diploid constructed by transducing the plasmid from strain $147\left(\beta . i^{-}{ }_{223} p^{+}\right)$into strain $\mu 56$, showed that, at most, the A-type enzyme amounted to $3 \%$ of the $\mathrm{C}$-type, and micro-constitutive mutations in the penicillinase system cannot, therefore, be counteracted in a diploid by the wild-type allele.

\section{Genetic location of some micro-mutations}

The positions of the micro-mutations $\mu 1, \mu 15, \mu 56$ and $\mu 88$ were mapped in relation to a known mutation in the structural gene, ${p^{-}}_{2}$; (Richmond, 1963, $1965 a$, $b$ ) and to the $\mathrm{Hg}$ and $\mathrm{em}$ loci, by taking advantage of the fact that the micro-strains

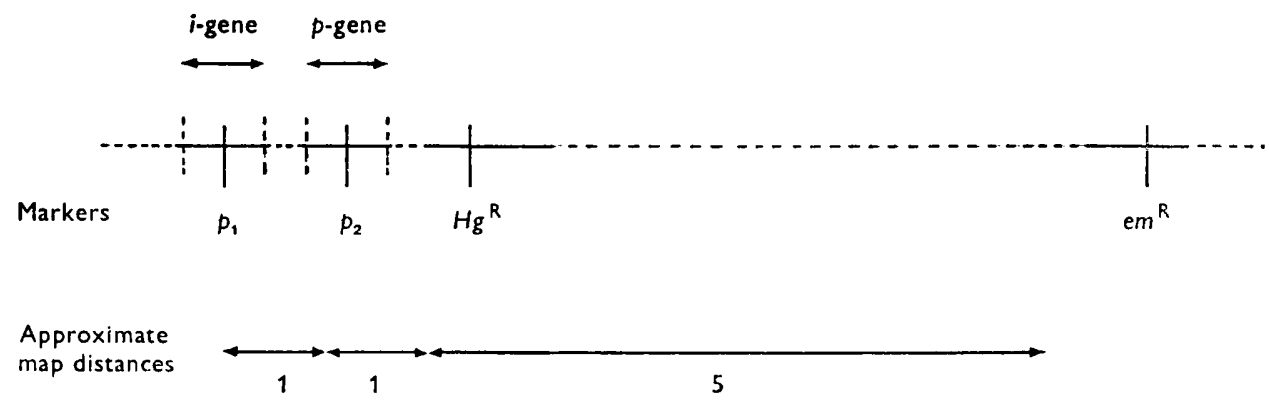

Fig. 1. Order and approximate distances between markers on the recombined $\alpha \ldots \gamma$ plasmid. Markers: $i$, penicillinase control (inducibility) gene; $p$, penicillinase structural gene; $\boldsymbol{H g}^{\mathrm{R}}$, resistance to mercuric chloride; $\mathrm{em}^{\mathrm{R}}$, resistance to erythromycin.

are genotypically $i^{+} p^{+}$. Previous experiments (Richmond, unpublished) have shown that the order of loci on the recombined $\alpha \ldots \gamma$ plasmid is i.p.Hg.em (Fig. 1) and when a cross of the type

$$
\left.\begin{array}{cc}
\alpha . i^{+} p^{+} . e m^{\mathrm{R}} \times \alpha \cdot i^{-}{ }_{1} p^{-}{ }_{2} . e m^{\mathrm{s}} \\
\text { donor } & \text { recipient }
\end{array}\right\}
$$

is carried out, the $i^{-}{ }_{1} p^{+} . e m^{R}$ recombinants occur at about $0.1 \%$ of the total number of erythromycin-resistant transductants. If the location of a micro-mutation lies between $i^{-}{ }_{1}$ and $p^{-}{ }_{2}$, the number of $i^{-} p^{+} . e m^{\mathrm{R}}$ recombinants obtained from the cross

$$
\alpha \cdot i^{+} \cdot \operatorname{micro} \cdot p^{+} . e m^{\mathrm{R}} \times \alpha \cdot i^{-}{ }_{1}{p^{-}}_{2} \cdot e m^{\mathrm{B}}
$$

should be less than the number obtained from cross (1). This result would also be expected if the micro-loci lay close to $\mathrm{em}$ but on the far side of that marker with respect to $p$; however, this alternative can be eliminated by a further experiment.

The micro-constitutive strains $\mu 56 . \mathrm{em}^{\mathrm{R}}$ and $\mu 88 . \mathrm{em}^{\mathrm{R}}$ were therefore used as sources of transducing phage and strain $8325\left(\alpha . i ._{1} p^{-}{ }_{2} . \mathrm{em}^{\mathrm{s}}\right)$ was used as recipient in a transduction experiment. The transductants were selected on erythromycin plates and counted after overnight growth. At the same time the number of magnoconstitutive recombinants on the plate was counted. The total number of erythromycin-resistant transductants and magno-constitutive recombinants was also measured in cross (1) as a control. With all the micro-strains tested, the proportion 
of the $\mathrm{em}^{\mathrm{R}}$ recombinants which were magno-constitutive $\left(i^{-} p^{+}\right)$was less than that found in the control cross (1) above (Table 4). This result suggests that the microloci of these strains lie between the $i_{1}^{-}$and $p^{-}{ }_{2}$ loci. The alternative interpretation (that the micro-locus lies close to $\mathrm{em}$-see above) can be eliminated by investigation of the products formed by transduction of the micro-mutants to a penicillinase-less strain. When an $\alpha \ldots \gamma$ recombinant plasmid was transduced in this way, the $\mathrm{em}^{\mathbf{R}}$ marker remained linked to the penicillinase genes in only about $85 \%$ of the recombinants (Novick \& Richmond, 1965). When certain of the (micro.em ${ }^{\mathbb{R}}$ ) markers

Table 4. Recombination data for the crosses $\alpha . i^{+} p^{+} . e m^{\mathrm{B}} \times i^{-}{ }_{1} p^{-}{ }_{2} . e m^{\mathrm{s}}, \alpha . i^{+}$. micro $1 . p^{+} . e m^{\mathrm{R}} \times \alpha . i^{-}{ }_{1} p^{-}{ }_{2} . e m^{\mathrm{s}}$, and $\alpha . i^{+}$. micro $56 . p^{+} . \mathrm{em}^{\mathrm{R}} \times \alpha . i^{-}{ }_{1} p^{-}{ }_{2} . e m^{\mathrm{s}}$

\begin{tabular}{|c|c|c|c|c|}
\hline Cross & Donor & Recipient & $\begin{array}{l}\text { Total } \mathrm{em}^{\mathrm{R}} \\
\text { transductants }\end{array}$ & $\begin{array}{l}i_{1}^{-} p^{+} . e m^{\mathrm{B}} \\
\text { recombinants }\end{array}$ \\
\hline Control & $\alpha . i^{+} p^{+} . e m^{\mathrm{R}}$ & $8325\left(\alpha \cdot i^{-}{ }_{1} p^{-}{ }_{2} . \mathrm{em}^{\mathrm{g}}\right)$ & 27,500 & 29 \\
\hline 1 & $\alpha \cdot i^{+} \cdot \mu \mathbf{1} \cdot p^{+} \ldots \gamma \cdot e m^{\mathbb{R}}$ & & 47,000 & 7 \\
\hline $\begin{array}{l}15 \\
56\end{array}$ & $\begin{array}{l}\alpha \cdot i^{+} \cdot \mu 15 \cdot p^{+} \ldots \gamma \cdot e^{\mathrm{R}} \\
\alpha, i^{+} \mu 56 \cdot p^{+} \gamma \cdot \mathrm{em}^{\mathrm{R}}\end{array}$ & As control & $\begin{array}{l}41,000 \\
52,000\end{array}$ & $\begin{array}{r}8 \\
10\end{array}$ \\
\hline $\begin{array}{l}50 \\
89\end{array}$ & $\alpha . i^{+}, \mu 89 . p^{+} \ldots \gamma \cdot e^{\mathrm{R}}$ & & 27,000 & 4 \\
\hline
\end{tabular}

Table 5. Co-transduction of the $p^{+}$and micro loci from the strains $\mu 56$ and $\mu 89$ to strain $8325(N)$

\begin{tabular}{|c|c|c|c|c|c|}
\hline Donor & Recipient & $\begin{array}{c}\text { Total } \\
\text { recipients } \\
\text { plated }\end{array}$ & $\begin{array}{c}\text { Total } p^{+} \\
\text {recipients }\end{array}$ & $\begin{array}{c}\text { Total } \\
p^{+} . e m^{\mathrm{R}} \\
\text { trans- } \\
\text { ductants }\end{array}$ & $\begin{array}{c}\text { Co-trans- } \\
\text { ductants } \\
\text { of } p^{+} \\
\text {and } e^{\mathrm{R}} \\
\quad(\%)\end{array}$ \\
\hline $\begin{array}{l}8325\left(\alpha \cdot i^{+}, \mu 56 \cdot p^{+} \ldots \gamma \cdot e m^{\mathrm{R}}\right) \\
8325\left(\alpha, i^{+}, \mu 89 \cdot p^{+}, e^{\mathrm{R}}\right)\end{array}$ & $\begin{array}{l}8325(\mathrm{~N}) \\
8325(\mathrm{~N})\end{array}$ & $\begin{array}{l}9 \times 10^{6} \\
7 \times 10^{6}\end{array}$ & $\begin{array}{l}87^{*} \\
57^{*}\end{array}$ & $\begin{array}{l}72 \\
44\end{array}$ & 86 \\
\hline
\end{tabular}

* Selected with $\frac{1}{15}$ th the concentration of penicillin used previously (Richmond, $1965 \mathrm{~b}$ )

were transduced to strain $8325(\mathrm{~N})$, and the transductants selected with penicillin, the micro-properties were co-transduced with the penicillinase locus in all the transductants tested whereas, as expected, there was only about $85 \%$ co-transduction of the $p^{+}$and $e m$ markers (Table 5). The micro-loci in strains $\mu 88$ and $\mu 56$ must, therefore, lie much closer to $p$ than to $e m$ and from the evidence of the previous cross their loci must be between the $i^{-}$and $p^{-}{ }_{2}$ loci.

\section{DISCUSSION}

The results reported here show that the micro-mutations in these strains do not lie in the penicillinase $i$-gene. If the genetic regions identified in the $\beta$-galactosidase system of Escherichia coli apply to penicillinase synthesis in Staphylococcus aureus, the mutations might be in the structural gene, $p$, or in a region analogous to the 'operator' (Jacob \& Monod, 1961, 1965).

As far as the micro-inducible strains are concerned, it is not possible to decide clearly between these alternatives. One possibility is a location in that part of the operator-as originally defined by Jacob \& Monod (1961)—which is responsible for controlling the rate of expression of the structural gene. A location in a promoter of the type defined by Jacob \& Monod (1965) seems to be ruled out, since the properties 
of the micro-constitutive mutants cannot be reconciled with the division of the operator region into two segments (see below and Richmond, 1966). If the microinducible mutations lie within the structural gene they must be to the left of the $p_{2}$ locus (Fig. 1) and cause a lower rate of enzyme synthesis yet no change in enzymic properties. Theoretically, behaviour of this kind could arise from a structural gene mutation which changed one DNA codon to an alternative codon for the same amino acid or to that of another amino acid whose insertion did not alter enzymic properties. To give the observed phenotypes, however, such a genetic change would have to cause a lower rate of reading of the structural gene whether at the transcription (DNA to RNA) or translation (RNA to protein) level. At the transcription level, the limitation could conceivably arise from a poor supply of the specific transfer RNA required to recognize the 'new' RNA-codon specified by the altered structural gene. An explanation of this kind has already been invoked to explain the properties of the 'polar' mutations in operons concerned with histidine (Ames \& Hartman, 1964) and arabinose biosynthesis (Lee \& Englesberg, 1963), and with lactose degradation (Signer, Beckwith \& Brenner, 1965). Unlike the penicillinase micro-mutations, however, these mutations appear to block completely the synthesis of the protein in whose gene they occur, and only affect the rate of synthesis of subsequent enzymes of the operon (Newton et. al. 1965).

As far as the micro-constitutive mutations are concerned, a location in the penicillinase structural gene seems most unlikely since they cause a loss of recognition of the inducer in addition to all the changes found in the micro-inducible strains. Under these circumstances, these mutations probably lie in a region of the operator type and this view is strengthened by their map location between the penicillinase $p_{2}$ and $i_{1}$ loci. Jacob \& Monod's original definition endowed the $\beta$-galactosidase operator with two roles-recognition of the $i$-gene product, and initiation (and perhaps rate control) of the expression of the operon (Jacob \& Monod, 1961) - and certain mutations in this region might be expected to affect both these properties and thus give rise to a micro-constitutive phenotype. Recent work with the $\beta$ galactosidase system, however, has now led Jacob \& Monod (1965) to suggest that the two operator functions are separate and to propose a new region- the promoter-which is alone responsible for expression of the operon, while the term 'operator' is retained for the region responsible for recognition of the $i$-gene product. Although the penicillinase micro-inducible mutants could be satisfactorily explained on the basis of a mutation in a promoter, the characteristics of the micro-constitutive mutants are not readily compatible with subdivision of the operator. The divided operator region, which appears to exist in the lac segment of Escherichia coli, may not therefore occur in the control regions of all inducible enzymes.

I wish to thank my colleagues, Professor M. R. Pollock, F.R.S., and Dr J.F. Collins, for many helpful discussions in connexion with this work. I would also like to thank Mr P. Thompson and Mr K. Frayn for their skilled technical assistance. 


\section{REFERENCES}

Ames, B. N. \& Hartman, P. E. (1963). The histidine operon. Cold Spr. Harb. Symp. quant. Biol. 28, 349.

Collins, J. F., Mandelstam, J., Pollock, M. R., Richmond, M. H. \& Sneath, P. H. A. (1965). A suggested phenotypic classification and terminology for enzyme mutants in micro-organisms. Nature, Lond. 208, 841.

Dubnau, D. A. \& Pollock, M. R. (1965). The genetics of Bacillus licheniformis penicillinase: a preliminary analysis from studies on mutation and inter-strain and intra-strain transformations. J. gen. Microbiol. 39, 195.

Green, S. M. (1962). Mercury sensitivity of staphylococci. J. clin. Path. 15, 249.

Hashimoto, H., Kono, K. \& Mitsuhashi, S. (1964). Elimination of penicillin resistance of Staphylococcus aureus by treatment with acriflavine. J. Bact. 88, 261.

$\mathrm{J}_{\mathrm{ACOB}}, \mathrm{F}$. \& MonoD, J. (1961). On the regulation of gene activity. Cold Spr. Harb. Symp. quant. Biol. 26, 193.

$\mathrm{J}_{\mathrm{ACOB}}$, F. \& MoNOD, J. (1965). Genetic mapping of the elements of the lactose region in Escherichia coli. Biochem. biophys. res. Commun. 18, 693.

LEe, N. \& Englesberg, E. (1963). Co-ordinate variations in induced synthesis of enzymes associated with mutations in a structural gene. Proc. natn. Acad. Sci., U.S.A. 50, 696.

Moore, B. (1950). A new screen test and selective medium for the rapid detection of epidemic strains of Staphylococcus aureus. Lancet ii, 453.

Newton, W. A., Beckwith, J. R., Zipser, D. \& Brenner, S. (1965). Nonsense mutants and polarity in the lac operon of E. coli. J. molec. Biol. 14, 290.

Novick, R. P. (1963). Analysis by transduction of mutations affecting penicillinase synthesis in Staphyloccocus aureus. J. gen. Microbiol. 33, 121.

Novick, R.P. \& Richmond, M. H. (1965). The nature and interaction of the genetic elements governing penicillinase synthesis in Staphylococcus aureus. J. Bact. 90, 467.

Richmond, M. H. (1963). Purification and properties of the exo-penicillinase from Staphylococcus aureus. Biochem. J. 88, 452.

Richmond, M. H. (1965a). Penicillinase plasmids in Staphylococcus aureus. Br. med. Bull. 21, 360 .

Richmond, M. H. (1965b). Dominance of the inducible state in a strain of Staphylococcus aureus containing two distinct penicillinase plasmids. J. Bact. 90, 370.

Richmond, M. H. (1965c). Wild-type variants of exo-penicillinase from Staphylococcus aureus. Biochem. J. 94, 584 .

Richmond, M. H. (1966). One-step micro-constitutive mutations in the penicillinase region of Staphylococcus aureus. Biochem. biophys. res. Commun. 22, 38.

Richmond, M. H., Parker, M. T., Jevons, M. P.\& John, M. (1964). A correlation between multiple antibiotic resistance and high penicillinase production in Staphylococcus aureus. Lancet i, 719.

Signer, E. R., Beckwith, J. R. \& Brenner, S. (1965). Mapping of suppressor loci in Escherichia coli. J. molec. Biol. 14, 153. 